\title{
PLATO IN THE ACADEMY: SOME CAUTIOUS REFLECTIONS John Glucker
}

I shall deal here with a question of method: how to be fair to scanty evidence. Plato lived in his house near the Academy for over forty years, and one assumes that this is where he wrote most, or all, of his dialogues. Yet we have extremely meagre indications of his other activities in this hub of scholarship and thought. I shall not deal here with his activity as a philosophical thinker except in a few contexts where some of it may have some bearing on our main theme. As we all know, Plato has been depicted over the generations as a Socratic Pythagorean with Heraclitean infuences; a sceptic; a para-Stoic; a Neo-Platonist; a precursor of Christianity; a prefiguration of Hegelian ontology; a destroyer - together with Euripides and Socrates - of the true Tragic Spirit of the Greeks; a neo-Kantian; an existentialist; an analytic philosopher manqué, and a post-modern pharmacist. All this where we have volumes of ancient evidence - but there we are faced, of course, with the lubricous issue of philosophical exegesis. Our problem in the present study is of a different nature. It is chiefly historical, and we have more lacunae than solid facts in our meagre evidence.

Indeed, the issue of Plato's teaching activities is like a jigsaw puzzle where most of the parts are missing. Philosophical scholars tend, by and large, to imitate nature in not liking a vacuum. They have, therefore, the tendency to bridge over the gaps and make assumptions ${ }^{1}$ where evidence is lacking. By and large, one detects

1 I have not compiled a long list of places where we are told that 'one must assume...', and the like: it would have occupied a whole booklet. Here are some examples. Konrad Gaiser, Platons ungeschriebene Lehre ${ }^{2}$, Stuttgart 1968, p. 2: "... und im übrigen ist anzunehmen"; p. 28: "Freilich gibt es so gut wie keine direkte Zeugnisse dafür, daß sich Platon in der Schule ausführlich über geschichtsphilosophische Fragen geaüßert hat. Es ist jedoch anzunehmen...". Paul Shorey, What Plato Said, Chicago 1933 and reprints, pp. 29-31, "We may suppose"; "We may fancy if we please"; "We may see in the Parmenides"; "We may presume" - and more of the same. The whole section begins with the words "Somewhat less fanciful \{and therefore "we may fancy if we please"? JG\} are the better-founded 
three types of answer to the question of what Plato taught in the Academy - assuming, that is, that he did teach in the Academy at all.

The first, and rather widespread, suggestion is that the "programme of studies" in the Academy followed the plan for the education of the Guardians in Plato's Republic. This was expounded in some detail by John Burnet: ${ }^{2}$ the teaching included arithmetic, plain and solid geometry, astronomy, harmonics - and, of course, dialectic. Paul Shorey ${ }^{3}$ adds to the programme of studies in Republic also Parmenides as "a lesson in logic devised by Plato to exercise the wit of his students"; and sees in Philebus "a report of a discussion guided by Plato". The methods of classification in Sophist and Politicus may also have "found its reflection in the exercises of the school". ${ }^{4}$ Shorey devotes some space also to "occasional lectures by Plato himself", of which Пepì $\tau$ ' $\dot{\alpha} \gamma \alpha \theta$ oṽ is a specimen, and also to research in mathematics and astronomy; but the main 'teaching programme' is derived from the dialogues.

Doubts have been expressed on this point, and rightly so. The best objection known to me has been formulated by Henri-Irénée Marrou. ${ }^{5}$ None of our sources, says Marrou, tells us anything about such a 'programme of studies'. It is unlikely that programmes of education like those in Republic or Laws were ever intended for the

conjectures of modern scholarship with regard to the nature of Plato's teaching in the Academy".

2 John Burnet, Greek Philosophy, Thales to Plato, London 1914 and reprints, "THE PROGRAMME OF STUDIES", pp. 182-187. Burnet has already - pp. 180-181 - also accepted the reports on Пвpì $\tau$ ' $\alpha \gamma \alpha \theta$ oṽ in a 'maximalist' interpretation of 'regular lectures'. 3 See note 1 above.

4 Theodor Gomperz, Griechische Denker, Eine Geschichte der antiken Philosophie, 2e Auflage, IIer band, Leipzig 1903, p. 222, also suggests that some of the late dialogues reflect Plato's teaching in smaller "Schülerkreise", which were not unlike our own "seminaristische Übungen". See, for a similar view, Émile Bréhier, Histoire de la philosophie 1, Paris 1951, p. 97: "En quoi consistait l'enseignement de Platon? C'est ce qu'il est difficile de savoir, parce que la plupart de ses oeuvres, destinées à un large public, n'en doivent pas être le reflet; il faut en excepter pourtant ces sortes d'exercises logiques que sont la seconde partie du Parménide, et les débuts du Théétète et du Sophiste; si l'on fait attention que ces exercises sont destinés à éprouver la vigueur logique de l'étudiant...'

5 Henri-Irénée Marrou, Histoire de l'Éducation dans l'Antiquité, 2nd edition, Paris 1965, pp. 114-115. 
Academy. Both dialogues are "utopian", blueprints for ideal states, and their programmes are organized by age-groups and abilities. One may also add that the dialogues were written for publication and addressed to a readership which included people outside the Academy.

Another suggestion, a little less widely held, was that Plato used his own dialogues as textbooks in teaching his pupils in the Academy. We have seen that Shorey takes Parmenides, Sophist and Politicus as reflecting such exercises. A representative of this view, within limits, is Gilbert Ryle. ${ }^{6}$ Ryle does point out that "Plato composed his elenctic dialogues before his Academy was founded", but continues: "We have indeed good reasons to think that the Timaeus and Parmenides were designed for academic listeners only." 7 "The Timaeus...", he says elswhere, "${ }^{8}$ "was reserved for the instruction of students in the Academy". This involves him in speculating about the various 'performances' of some of the other dialogues in various festivals and games. This is only one of the eccentricities of this fascinating book. But it does take it for granted that some dialogues were used in teaching in the Academy. If we take the more pedestrian, and more widely accepted, view that all the dialogues were written for publication - or even if we accept Ryle's thesis that some dialogues were first used only for teaching in the Academy - we may ask how one imagines that the dialogues were used in courses in the Academy. Were they just 'performed', as Ryle sometimes suggests? But even he assumes that they were also used "for the instruction of students". Would Plato explain to his students what is wrong with the sophisms used by Socrates in Republic $I,{ }^{9}$ or with the argument at

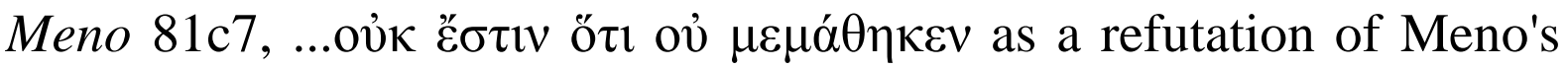

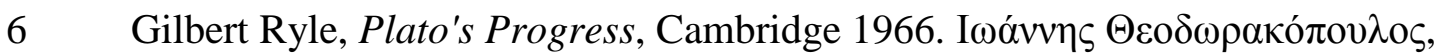

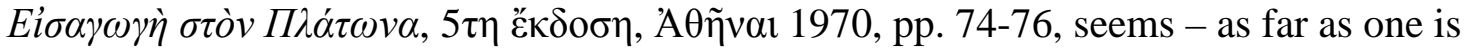
entitled to draw such pedestrian conclusions from his sublime formulations - to take it for granted that the Platonic dialogues, especially those where Socrates is the 'hero', were studied and taught in the Academy.

7 Ryle, pp. 42-3.

8 Ryle, p. 83.

9 See Ivor Ludlam, 'Thrasymachus in Plato's Politeia I' in Amos Edelheit (ed.), Maynooth Philosophical Papers 6, 2011, Maynooth 2012, pp. 18-44.
} 
argument that one cannot learn what one does not know? ${ }^{10}$ Or with the 'telegraphic' proof of the immortality of the soul at Phaedrus 245c5-246a2? ${ }^{11}$

Another way of taking the dialogues to be at least part of the materials used for Plato's teaching in the Academy has been proposed by our colleague Professor Szlezak. ${ }^{12}$ (A 1-2 on handout). But Szlezak's suggestion is that the dialogues, or some of them, were read in the Academy in conjunction with the students' "training in Platonic philosophy". In the context of the school Szlezak adheres to, the Tübingen School, this training would mean regular courses of lectures on the One, the Indivisible Dyad, and the whole complex system of philosophy reconstructed by the Tübingen Platonists from these a $\rho \chi \alpha i$. The evidence for this system is what we are told about Plato's /lecture?/course of lectures?//regular courses of lectures?/ "On the Good". Dealing with this issue is almost like rem actam agere. Let us, however, look again at what the sources tell us about this/ese lecture/s. I shall not enter into the contents, or the possible implications of these contents - or else we shall be sitting here $\mu \varepsilon \dot{\chi} \chi \rho$

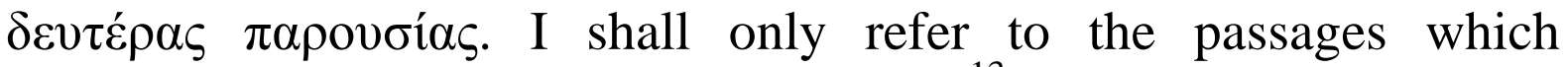

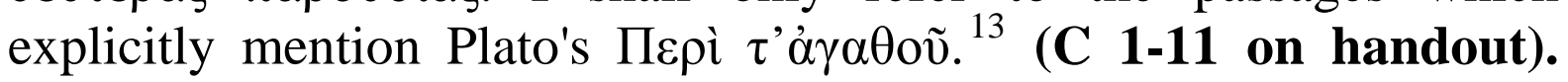
Before we do that, however, we should take heed of Giovanni Reale's sombre warning against those who may dare disagree with the Tübingen reconstruction of the philosophical system of Пвpì

10 A number of adherents of the "Theory of Reminiscence" have suggested that the perfect tense does not mean here that the soul has actually learned, but only that she is "in a

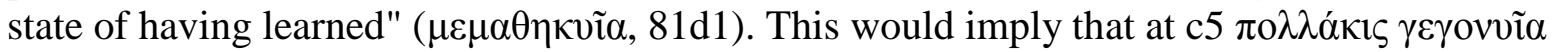
would only mean that "she is the state of having been born many times", and at c6 $\dot{\varepsilon} \omega \rho \alpha \kappa v i \tilde{\alpha}$ would mean that "she is in the state of having seen". And when Phidippides came to Athens

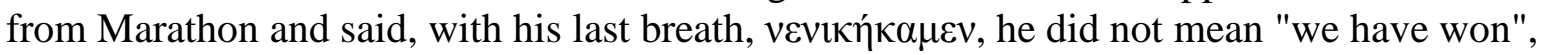
but merely that "we are in the state of people who won". In any case, even if the soul has lived many times here and in Hades, why should this necessarily prove that she has seen

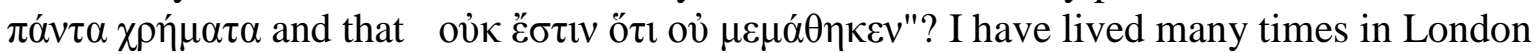
for long periods, and yet there are many parts of it which I have never seen. See, for some of the problems involved, the detailed discussion in R. W. Sharples (ed., transl., comm.), Plato: Meno, Warminster 1984, pp. 147-149.

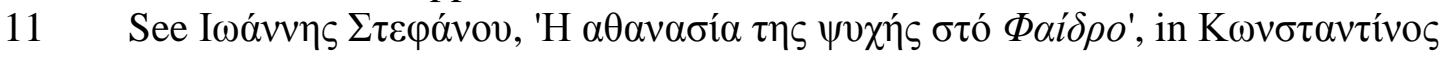

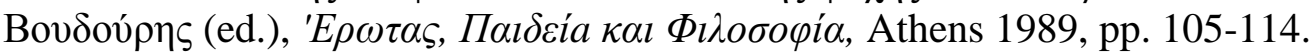

12 See A 1-2. in the handout.

13 See C 1-11 in the handout. 
$\tau^{\prime} \dot{\alpha} \gamma \alpha \theta$ oṽ. ${ }^{14}$ (B 1-2 on handout).

In my Section $\mathrm{C}$, I have arranged the pieces of evidence on Plato's Пepì $\tau$ ' $\dot{\alpha} \gamma \alpha \theta$ oṽ in three sub-sections, according to the main emphasis in the story told in each of them. 1-3 describe what seems to be a public lecture by Plato, which most of the audience found

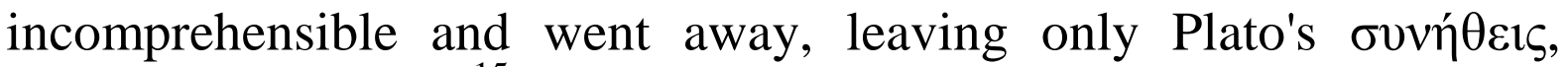
$\dot{o} \mu \imath \lambda \eta \tau \dot{\varepsilon} \zeta$ or $\dot{\varepsilon} \tau \alpha i \tilde{\rho} \rho .^{15}$ 4-9 report in various details the contents of Пврі $\tau$ ' $\dot{\alpha} \gamma \alpha \theta$ oṽ, mainly the One, the Indivisible Dyad, and the various applications of this Dyad. Of these, 4-5 mention the names of some, at

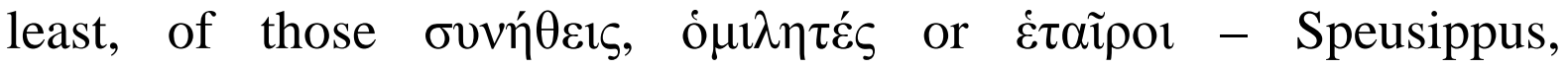
Xenocrates, Aristotle, Heraclides, Hestiaeus - and tell us that they wrote down what Plato said. 6-9 concentrate on the difference between these 'unwritten words' of Plato and his Timaeus, as indicated in Aristotle's Physics 209b11-16. 10-11 deal with what they call

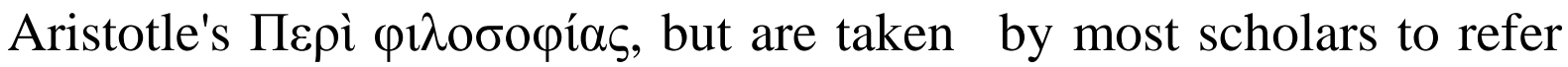

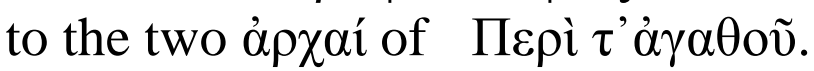

At the price of repeating old arguments, it would be hard to read

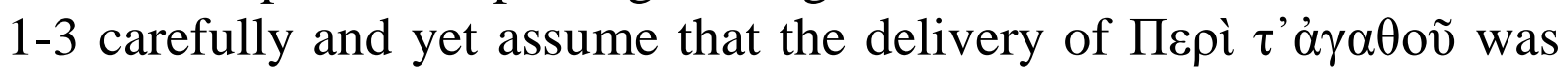
more than one single event. As pointed out long ago by G. J. De Vries, ${ }^{16}$ Aristoxenus, our source for 1 , was no friend of Plato, and would have been only too happy to point out that Plato drove away large crowds of listeners again and again - if that were what happened. Also, would Plato himself care to risk repeating such a humiliating performance more than once? Similar arguments are offered in Philip Merlan's posthumus article in the same periodical. ${ }^{17}$ Add to their arguments that, if these were recurring lectures - not to mention regular Lehrvorträge delivered by Plato year in, year out there would be no reason for his غं $\tau$ ĩpor to write them down, nor would Porphyry (5) describe these words as $\tau \dot{\alpha} \dot{\rho} \eta \theta \varepsilon ́ v \tau \alpha \alpha i v \gamma \gamma \mu \alpha \tau \omega \delta \tilde{\omega} \varsigma$ if

14 See handout B 1-2.

15 As can be seen from the headings of the passages in Section C, Gigon includes all of them among the fragments of Aristotle's $\Pi \varepsilon \rho \grave{~} \tau$ ' $\dot{\alpha} \gamma \alpha \theta$ oṽ. But our 1 is clearly by Aristoxenus, and claims to record what Aristotle used to say to his pupils. 2-3 may also depend on the same Aristoxenus story, adding some details. See our note 18 . The rest of these passages

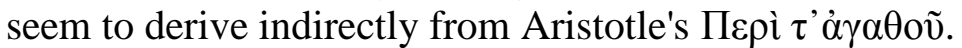

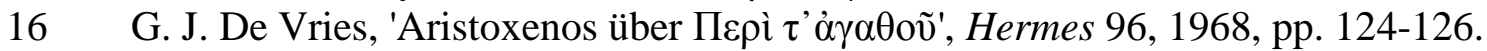

17 Philip Merlan, 'War Platons Vorlesung "Das Gute" Einmalig?", ibid. pp. 705-709. 
they represented common themes of Plato's regular lectures. Add to it - as Merlan does - that Themistius (2) tells us that Plato delivered Пepì $\tau$ ' $\alpha \gamma \alpha \theta o \tilde{~ i n ~ P i r a e u s . ~ W h e t h e r ~ T h e m i s t i u s ~ a n d ~ P r o c l u s ~(2-3) ~ w e r e ~}$ entirely dependent on Aristoxenus (as Gaiser takes for granted) or not, I see no reason to assume that Themistius would go out of his way to invent such an 'unnatural' venue. ${ }^{18}$

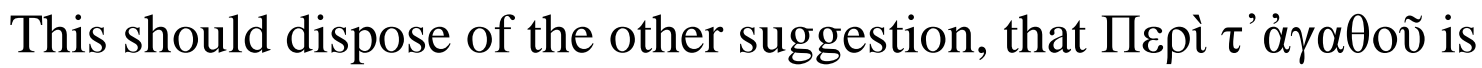

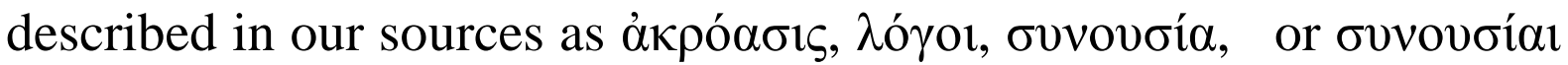
since all these words refer to regular instruction. In fact, none of these is, at the time of Plato and Aristotle, a strictly technical term, and only the plural ovvovoíal, which appears in 7, 9, 10 and 11, must refer to more than one occasion. Three of our sources - Aristoxenus (1), Proclus (3), and Alexander, quoted by Simplicius (4) use

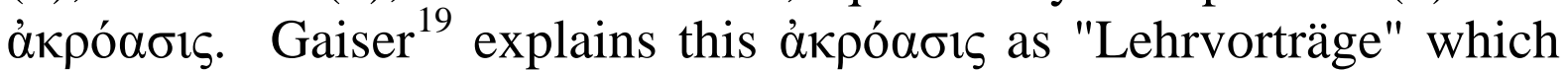
"allgemein zugänglich waren". My objections in the last paragraph need not be repeated. But let us look at these words. Despite the

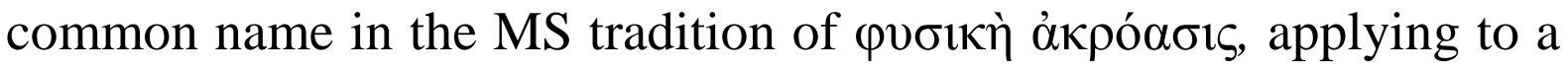

18 Gaiser (note 1 above), at the end of his note to his testimonium 1 (=our 1 ), pp.

452-3, writes: "Von Aristoxenos abhängig und also ohne selbstständigen Quellenwert sind die Darstellungen des Themistios [our 2] und Proklos [our 3], die in der Übertreibung des mißerfolges noch weiter gehen". Neither of these two passages is included in any edition of Aristoxenus. Bruno Colpi, Die $\pi \alpha i \delta \varepsilon i \alpha$ des Themistius, ein Beitrag zur Geschichte der Bildung im vierten Jahrhundert nach Christus, Bern 1987, p. 121, note 99, cites these words of Gaiser and remarks: "Vielleicht läßt sich doch die Frage stellen, ob der Aristoteliker Themistius nicht aus Aristoteles (de bono p. 111 Ross) selbst, auf dem sich Aristoxenus beruft, geschöpft hatte". Gigon takes this account of Themistius as derived from Aristotle's Пвpì $\tau^{\prime} \dot{\alpha} \gamma \alpha \theta$ oṽ. Themistius knew one or two things about Plato and Aristotle. He may have added, for rhetorical effect, the description of the various places, including the silver mines at Laurium, from which people flocked to hear Plato; but he is unlikely to have invented Piraeus as the place where these $\lambda$ ó or were delivered. Why should he? The Academy would be the natural place, and if imagination had a say in this, people would rather be made to flock there even from the Piraeus. Indeeed, $\mathrm{W}$.

K. C. Guthrie, A History of Greek Philosophy IV, p. 21, takes it for granted (having probably forgotten Themistius' evidence) that "The lecture must have been given in the gymnasium, a public part of the Academy precinct, where Sophists and others were wont to hold forth." I shall not attempt to examine the rest of Guthrie's discussion of Plato's 'instruction' (pp. 21-22).

19 L. c. note 1 above, p. 452 note. It would follow from his remark that the phenomenon of most listeners leaving half-way through the lecture was also a regular feature of these 'Lehrvorträge'. 
series of lectures (and this title is post-Aristotelian), ${ }^{20}$ this is not the usual sense of $\dot{\alpha} \kappa \rho o ́ \alpha \sigma i \varsigma$ : it usually refers to any spoken performance, ${ }^{21}$ and often clearly to a one-time performance. ${ }^{22}$ The singular form is attested by Porphyry (5). I would rather take his evidence than that of Asclepius (7); Philoponus $(9 ; 10)$ and Simplicius

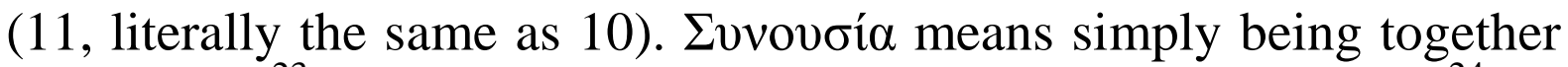
with others. ${ }^{23}$ Agathon's symposium is described as a ovvovoía. ${ }^{24}$ So is the discussion between Socrates and Protagoras. ${ }^{25}$ It is sometimes used in Sophistic contexts, as in that locus classicus, Apology 19e4-20a2. This sentence is evidence enough for the non-technical sense of the word: young people who can $\tau \tilde{\omega} \nu \dot{\varepsilon} \alpha v \tau \tilde{\omega} \nu \pi \mathrm{o} \lambda \iota \tilde{\omega} \nu \pi \rho$ oĩ $\alpha$ $\sigma v v \varepsilon \tilde{i} \alpha_{1} \tilde{\omega} \hat{\alpha} v \beta o v ́ \lambda \omega v \tau \alpha$ are persuaded by some famous Sophists $\tau \hat{\alpha} \varsigma$

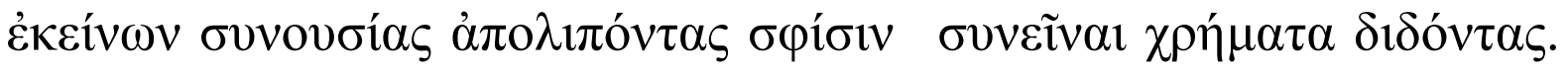
The 'being together' itself applies here to anyone, Sophists or any ordinary citizens. Any ordinary citizens, at least, are nowhere attested as delivering 'Lehrvorträge'. And, if the Seventh Epistle is genuine, it is again Plato himself who uses ovvovoía a few times in the non-technical sense of 'being together'. Moreover, in what may be the most famous passage in that letter, ovvovoía is expressly distinguished from $\sigma 0 ́ \gamma \gamma \rho \alpha \mu \mu \alpha$ and $\mu \alpha \dot{\theta} \eta \mu \alpha{ }^{26}$ (D on handout). As to $\lambda$ ó casual talk, in a lecture, in a series of lectures, in a conversation of any sort. To conclude from such words that Пepì $\tau^{\prime} \dot{\alpha} \gamma \alpha \theta$ ov was a regular series of lectures or seminars is to read far too much into our

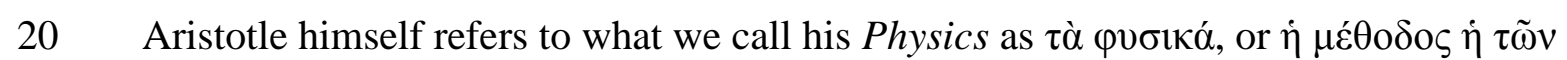

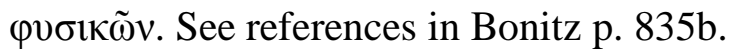

21 E. g. Thucydides I. 22.4. Cicero, Att. XV. 17.2

22 Hippocrates, Praecepta XII. Aristotle, Poetics 1459b22. Suetonius, Gramm. 2: ... plurimas acroasis subinde fecit assidueque disseruit. Vitruvius X. 22. 3.

23 E. g. Plato, Laws I, 624b1; 639d3.

24 Plato, Symposium 172a7. b7. c1 et al.

25 Plato, Protagoras 337b3.

26 See handout, section D. If the Seventh Epistle is not genuine, then we have here an extra-Platonic piece of evidence for the informal nature of бvvovoí $\alpha$ in a Platonic context. For Socratic ouvovoía see also John Patrick Lynch, Aristotle's School, A Study of a Greek Educational Institution, Berkeley. Los Angeles. London 1972, pp. 42-44. Lynch, however, limits his discussion to passages where ovvovoía is explicitly connected with Socrates' 'teaching activities'. 
scanty evidence, disregarding the contemporary usage of these words.

What, then, did Plato do with his 'students', other than what seems almost certainly to be the one lecture Пєрі $\tau$ ' $\dot{\alpha} \gamma \alpha \theta$ oṽ, open to the public, and quite probably delivered in the Piraeus? We have two ancient pieces of evidence, one contemporary and one from an Epicurean source, written about three centuries later, but most probably relying on near-contemporary sources.

The first passage comes from an unknown comedy by Plato's contemporary Epicrates.(E on handout). This passage is well-known, and yet it is absent from Riginos' Platonica. ${ }^{27}$ A number of German scholars regarded it as - what else? - seminars in botany and zoology. ${ }^{28}$ Gaiser, ${ }^{29}$ more cautiously, calls it merely "biologische Klassifizierung in der Akademie". Cherniss ${ }^{30}$ dismisses the whole story as pure invention, based partly on a scene of Aristophanes, partly on the method of division exemplified in Sophist and Politicus, and of no greater historical value than the Aristophanic

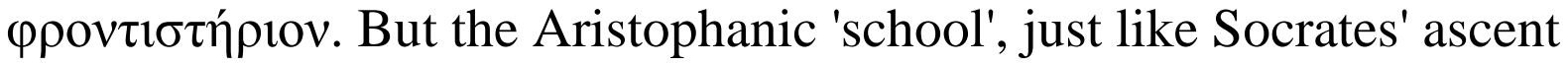
to the clouds, were indeed pure inventions. Middle comedy is somewhat less imaginative and more down to earth. Assume that Epicrates is describing some practice of Plato and his friends. It occurs quite clearly not in Plato's house or garden, but in the public gymnasium. The activity is described by the verb $\delta 1 \alpha \tau \rho i ́ \beta o v \sigma ı v$, and in our context it does not even have the later sense of 'course, seminar'. ${ }^{31}$ It is more reminiscent of Socrates' activity described at the beginning

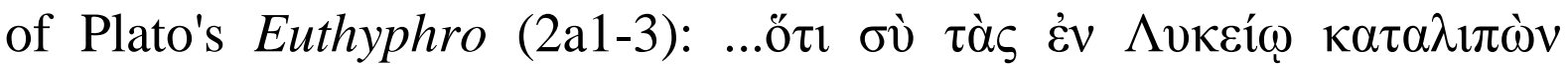

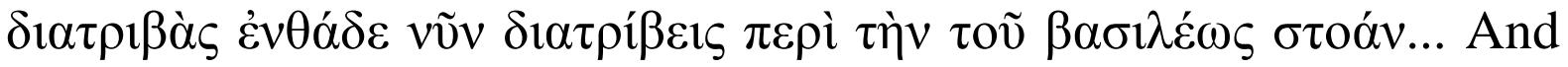
to anticipate any suggestion by future scholars that Socrates is 'holding forth' at that stoa, Euthyphro - who, we remember, had the

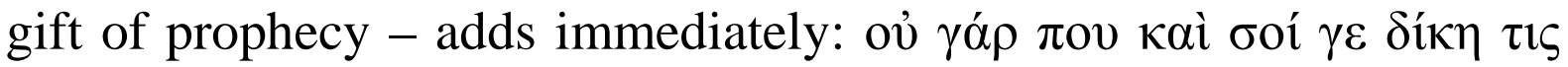

27 Alice Swift Riginos, Platonica, The Anecdotes Concerning the Life and Writings of Plato, Leiden 1976.

28 See references in Harold Cherniss, The Riddle of the Early Academy, Berkeley and Los Angeles 1945, p. 99, note 4.

29 (See note 1 above), fragment 6, pp, 450-451.

30 (Note 28 above), pp. 62-63.

31 John Glucker, Antiochus and the Late Academy, Göttingen 1978, pp.162-166. 


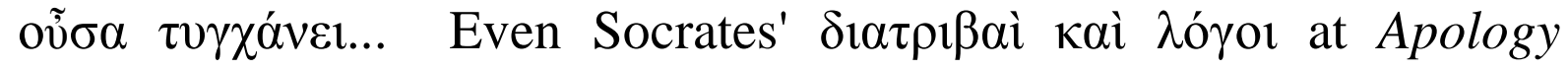
37b8-c1 and Gorgias 484e2-3 are not exactly academic (or Academic) seminars or lectures: they are things said in public and addressed to a general public. It is no accident that the Cynic sermons, addressed to a wide public, were called $\delta i \alpha \tau \rho \imath \beta \alpha i$. Moreover, the practice of philosophers coming to a gymnasium and posing questions to young people should be known to us from the first few pages of Euthydemus (also taking place in the Lyceum), and the emphasis on

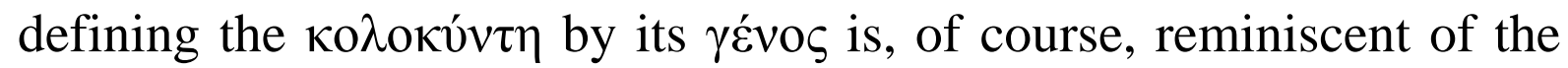
Eleatic's demand to define by division into proper $\gamma \varepsilon \dot{v} \eta \eta$. Even assuming that this scene is no pure invention by the comic poet, it does not seem to provide us with any evidence of teaching activities directed at some proper students of Plato. ${ }^{32}$

Our other source is Philodemus' History of the Academy, as a combination of Pap. Hercul. 1021 and 164 is now called. ${ }^{33}$ As Dorandi points out in his Introduction, ${ }^{34}$ and throughout his

32 One has no evidence either way for the historicity or otherwise of the story about the quarrel between Aristotle and Plato in Plato's last year, told by Aelian, VH 3, 19 (ed. Mervin B. Dilts, Stuttgart 1974, pp. 50-52), but some of the expressions used there seem to be

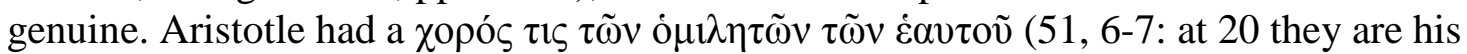

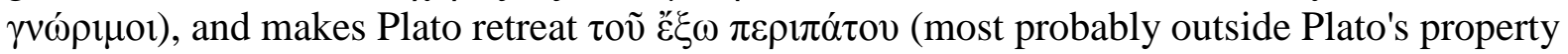

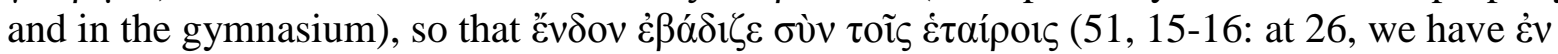

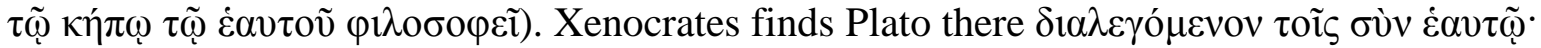

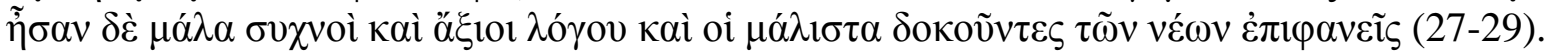
There can be little doubt about $\delta i \alpha \lambda \varepsilon \gamma o ́ \mu \varepsilon v o \varsigma$. This activity is then described as ó $\mu \imath \lambda i ́ \alpha$ (30), which can be used for any social intercourse or familiarity (we remember Aristotle's ó $\mu \lambda \eta \tau \alpha i$ ) and by $\sigma v v o v \sigma i ́ \alpha$ (32), which we have discussed earlier. As we have noted, neither has, in such contexts, any formal or institutional connotation. The young 'students' are $\dot{\varepsilon} \tau \alpha$ ĩpor, and Plato used to converse with them walking in the peripatos of the gymnasium. Another interesting point: in Aelian's story (51, 13-14), Aristotle

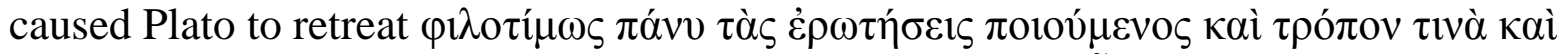

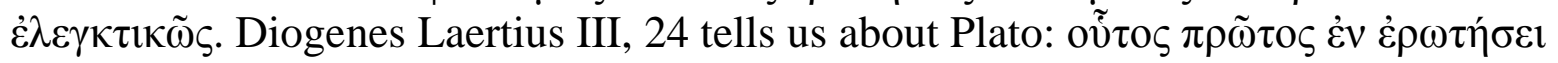
$\lambda$ ó ov $\pi \alpha \rho \eta ́ v \varepsilon \gamma \kappa \varepsilon v$, and refers to Favorinus as his source. On $\dot{\varepsilon} \rho \omega ́ \tau \eta \sigma 1 \zeta$ as a manner of

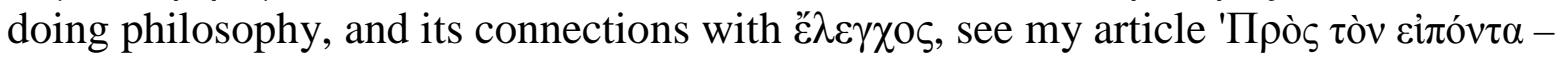
Sources and Credibility of De Stoicorum Repugnantiis 8', Illinois Classical Studies XIII, 1989, pp. 473-489.

33 Latest and by far best edition: Filodemo, Storia dei Filosofi [.] Platone e l'Academia, (P.Herc. 1021 e 164)... a cura di Tiziano Dorandi, Napoli 1991. (Henceforth "Dorandi").

34 Section ii, LE FONTI, pp. 83-99. 
commentary on the Plato sections, ${ }^{35}$ Philodemus used contemporary and near-contemporary sources like Philip of Opus, Hermodorus, Dicaearchus and Antigonus of Carystus. Plato is praised (I, 9ff.) as the one who "increased philosophy... and attracted innumerable people to it ". Here one would expect a mention of his extensive

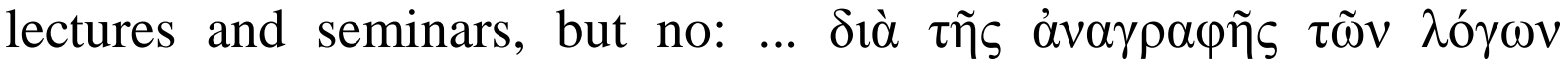
(14-15: some editors suggest $\delta 1 \alpha \lambda$ ó $\gamma \omega v)$. At I, 16-41, we have some indication - the text is rather lacunose here - of Plato making people turn to philosophy by showing them their ignorance; but the only indication that this involved teaching is Gaiser's reading $\delta i \delta \alpha \sigma \kappa \alpha ́ \lambda$ ov (adopted by Dorandi) at 41, where previous editors read $\delta 1 \alpha \delta$ ó $\chi 0 v$. Since later, at V, $35 \mathrm{ff}$., we have a list of $\Pi \lambda \alpha \dot{\tau} \omega v$ o $\mu_{\alpha \theta \eta \tau \alpha i ́}$, even the reading $\delta 1 \delta \alpha \sigma \kappa \alpha ́ \lambda o v$, if correct, should not surprise us. After all,

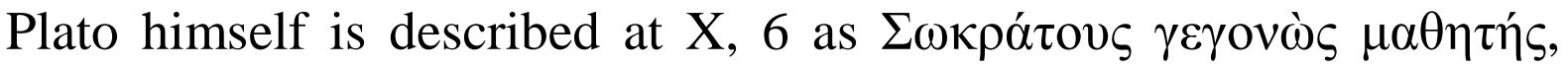
and Socrates gave no formal lectures or seminars. Plato's main praise

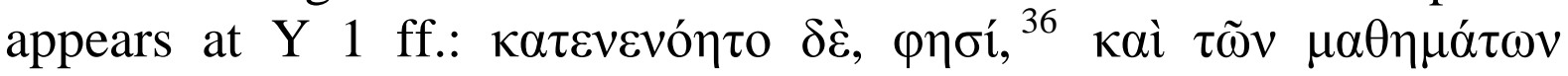

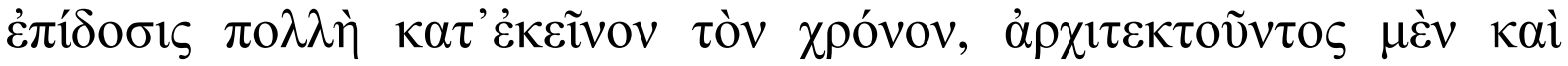

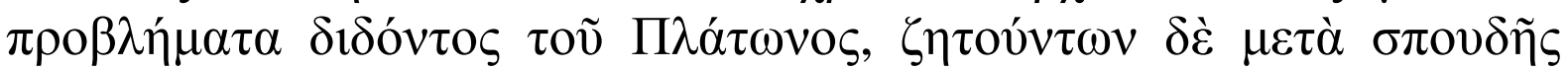
$\alpha u ̛ \tau \grave{\alpha} \tilde{\omega} \nu \mu \alpha \theta \eta \mu \alpha \tau \imath \kappa \tilde{\omega} v$. Philodemus proceeds to mention 'metrologia', geometry, mechanics and optics. The text becomes lacunose again here, but at 2 we have $\varphi$ oı $\eta \tau \tilde{\omega} v$, a word which already in Plato (e.g. Euthyd. 295d5-7) means 'a pupil' (and today means 'a student'). Here, at last, are our students, taking proper formal courses... But hold! Did Euthydemus and Dionysodorus give regular formal lectures? And a few lines below, at 29, we encounter yet again our friend

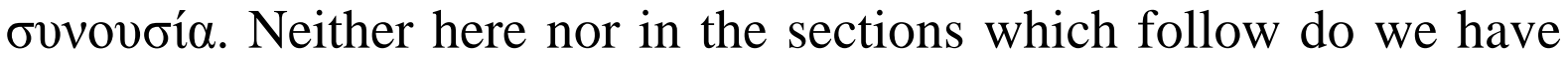
any evidence for any formal teaching activities, if there were any. I see no reason to fill the gap, if a gap it be. ${ }^{37}$

35 Pp. 203-224.

36 That is, Philodemus' source, probably here Dicaearchus: see II, 5.

37 This may be the place to cite a somewhat neglected piece of evidence (?). Riginos (note 27 above), p. 128, cites what she calls "a humorous fabrication given by a fifth century Neoplatonist and based on a specific passage in the Phaedrus" (275c-276d). Here is her rendering of Hermias, In Phaedrum 275c (p. 258 Couvrier): "A student wrote down all of Plato's lectures. Later, when he was travelling by boat, his notes were lost. He then returned to Plato and said he knew from experience the truth of Plato's maxim that one should write not in books but in men's souls." Here, then - at last! - we have evidence, from a pupil of 
One thing which emerges from all the passages referring back to $\Pi \varepsilon \rho \grave{~} \tau^{\prime} \dot{\alpha} \gamma \alpha \theta$ oṽ is that in that lecture Plato referred, at least, to the One and the Indivisible Dyad as $\alpha \rho \chi \alpha i$, and expanded on some of the applications of the Dyad. Considering that both Alexander of Aphrodisias and Porphyry (C 4-5 on handout) tell us that it was not only Aristotle who took down what Plato said on that occasion, but also other $\dot{\varepsilon} \tau \alpha$ inpor such as Speusippus, Xenocrates, Hestiaeus and Heraclides, it would be hazardous to dismiss all this - which seems to agree with much of what Aristotle says in chapter 6 of the first book of Metaphysics (esp. 987b19ff.) - as the sheer invention of Aristotle, who did not understand his Platonic dialogues, as Cherniss has done. But in the same chapter of Metaphysics (esp. 987b7-9) we are also told that Plato was the 'onlie begetter' of the 'theory of Ideas'. Yet in a sufficient number of places in Metaphysics, Physics and Topics, Aristotle speaks of "those who have postulated (or similar expressions) the Ideas". (See Section F on handout). This has often been dismissed out of hand, since - as we all know - Plato and the Theory of Ideas are inseparable. ${ }^{38}$ "The use of the plural..."' we are

Syrianus and a friend of Proclus, that Plato gave regular lectures. But hold! Here is the

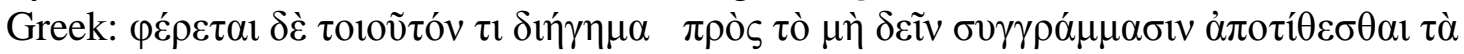

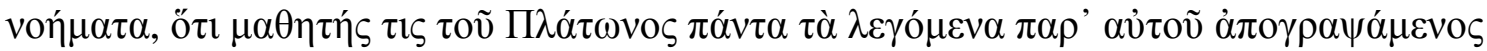

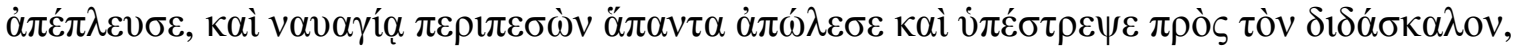

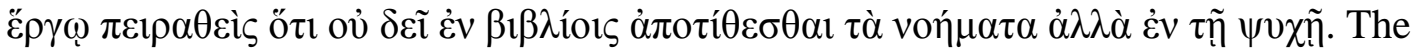

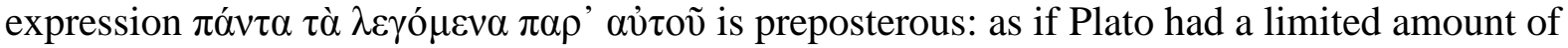
philosophy to teach, repeated it regularly, and if you lost it you could come back for the

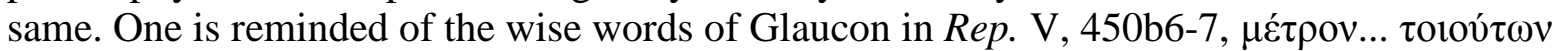

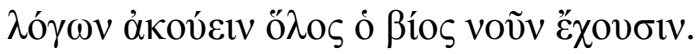

38 See, e.g., Harold Cherniss, Aristotle's Criticism of Plato and the Academy, Baltimore 1944 and reprints, p.186, note 108, referring to recent (then) publications; and especially G. C. Field, Plato and his Contemporaries, London 1930 and reprints, p. 208. W. D. Ross (ed., comm.), Aristotle's Metaphysics... Volume II, Oxford 1924 and reprints, pp. 420-421 (on 1078b11), is somewhat indecisive. On p. 420 he states plainly that the comparison between A, 987 and M, 1028 "shows clearly that Aristotle means Plato." On the next page, however, he suggests that "The main difference between $\mathrm{A}$ and $\mathrm{M}$ here is that $\mathrm{M}$, in using the phrase oi

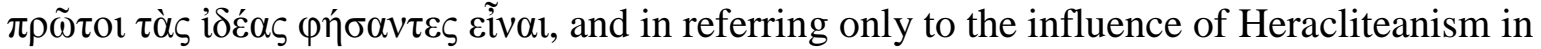
general and not to Cratylus in particular, perhaps suggests that Plato was one of a band of thinkers who by their united efforts arrived at the ideal theory". This, however, does not account for the large number of other anonymous references in the plural (handout, section 
told by Field, "proves nothing in Aristotle". No evidence is given: sic volo, sic iubeo. But is Aristotle incapable of uttering the name Plato when he is referring to Plato? I have collected a number of passages in all three works where Aristotle does not hesitate to mention Plato by name (See handout, Section G). In most of these places, Plato is mentioned in relation to themes with which we are familiar from dialogues like Theaetetus, Timaeus, Sophist and Phaedrus. Only in two of these passages does Aristotle connect Plato with i $\delta \varepsilon \dot{\varepsilon} \alpha$ or $\varepsilon$ i $\delta \eta$ (Met. Z, 2, 1028b19-22; Top. 148a14-22.) In neither of these places is Plato explicitly credited with inventing the Ideas. In the first passage we have his view on the relation between the $\varepsilon$ ir $\eta$ and the mathematical entities as contrasted with that of Speusippus. In the second, we have his definition of the Ideas as immortal and imperishable. This would still enable us, if we wished to make assumptions, to speculate on the nature of oi $\tau \grave{\alpha} \varsigma$ i $\delta \varepsilon \dot{\varepsilon} \alpha \tau \imath \theta \dot{\varepsilon} \mu \varepsilon v o 1$ and similar expressions as other pupils of Socrates, other members of the Academy - perhaps "the Friends of the Ideas" of Sophist - and the like. Plato, we could maintain, did not invent the Ideas, but only 'shared' them, and discussed them, with other members of the Academy. But such assumptions fail in the face of the close verbal similarities between Met. A, 6 and $M$, 4, where similar actions related to the Ideas are ascribed, virtually in the same words, to Plato in $A, 6$

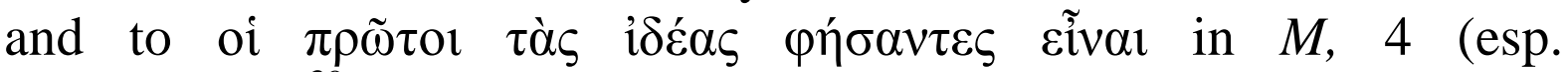
1078b11-12). ${ }^{39}$ These similarities have, of course, not escaped the notice of scholars; but as we have seen, the tendency has been to

F), as against the numerous references to Plato, only two of which connect him at all with the Theory of Forms (handout, section G).

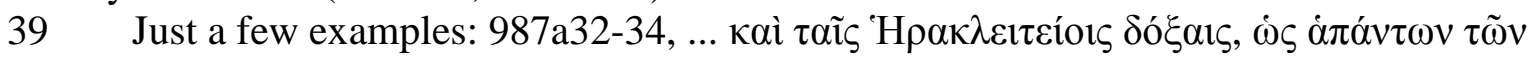

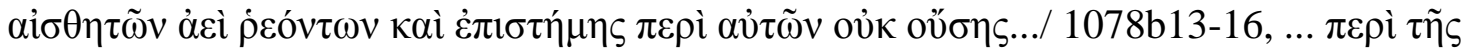

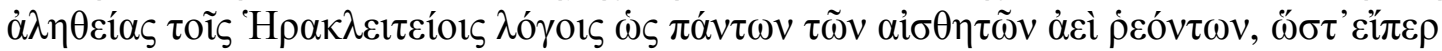

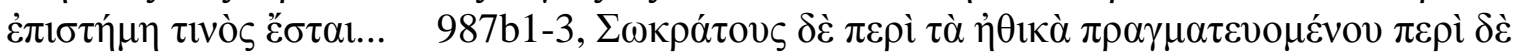

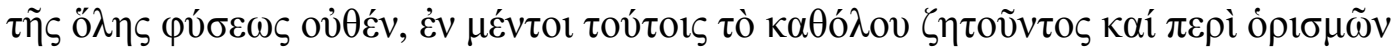

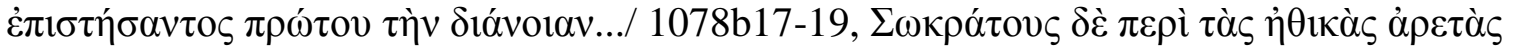

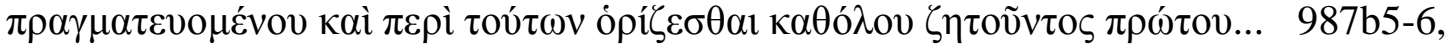

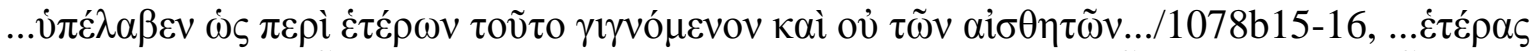

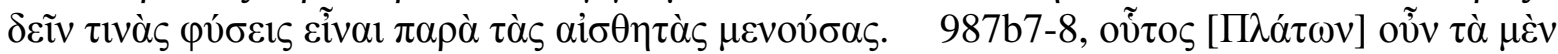

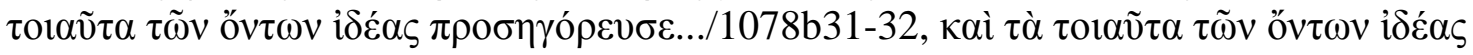
$\pi \rho \circ \sigma \eta \gamma \delta ́ \rho \varepsilon v \sigma \alpha v \ldots$ 
regard the plural as singular, and oi $\tau \grave{\alpha} \varsigma$ i $\delta \varepsilon \dot{\varepsilon} \alpha \varsigma$ $\tau \imath \theta \varepsilon \mu \varepsilon v o r$ as some sort of euphemism for Plato. Aristotle, needless to say, had a fairly decent Classical education, knew the distinction between singular and plural, and could recognize a Plato when he saw one. What, then, are we to do with this problem?

I do not have an answer. I can only point to some possibilities. One suggestion was made long ago by Richard Shute: ${ }^{40}$ The Metaphysics as we have them are not part of the collection of works which made their way to Skepsis and were then discovered by Tyrannio. They consist of a collection of treatises written by Aristotle at various times - hence the similarities, differences and confusions. A more extreme approach is that of Felix Grayeff, ${ }^{41}$ according to which the whole Aristotelian corpus as we have it is not 'pure' Aristotle, but rather a collection of works based on lecture notes of two or three generations of Peripatetics. Most scholars, however, tend to accept most parts of the corpus as basically Aristotle's, with some possible interpolations and additions. One way of dealing with double versions like the one we have between $A$ and $M$ is to accept the approach of Werner Jaeger and ascribe each of these books to a different period in Aristotle's life. ${ }^{42}$ Jaeger (pp. 192-193) takes

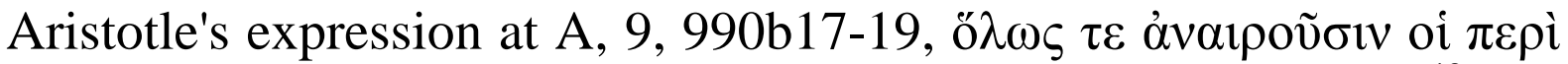

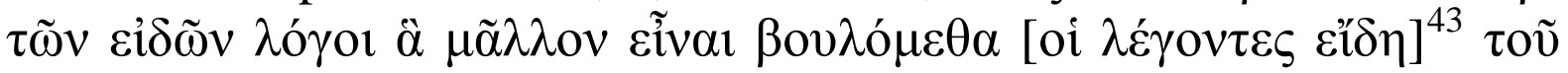

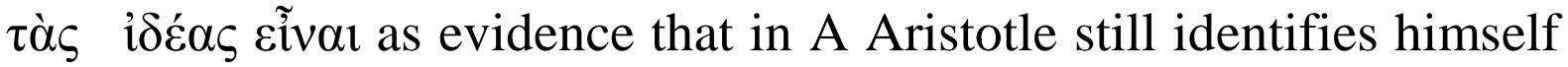
with other members of the Academy, and he therefore maintains that A was written during Aristotle's sojourn in Assos. But assume that we accept this interpretation, what reason had Aristotle, when he was in

40 Richard Shute, On the History of the Process by which the Aristotelian Writings arrived at their Present Form, Oxford 1888, pp.136-138.

$41 \quad$ Felix Grayeff, Aristotle and his School, London 1974.

42 Werner Jaeger, Aristoteles, Grundlegung einer Geschichte seiner Entwicklung, Berlin 1923, Ch. 3, 'Das Urmetaphysik', pp. 170-199 and Ch. 4, 'Die Entwicklung der Metaphysik', pp. 200-236.

43 These words are secluded by Blass as 'an intrusion' from M4, 1079a14-15. Jaeger also reads $\beta$ ov $\lambda$ ó $\mu \varepsilon \theta \alpha$ with the 'oldest and best' MS E. So does Ross, and most editors since

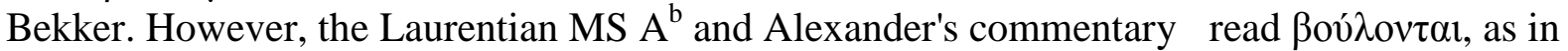
the parallel sentence in $\mathrm{M}$ - and all MSS have the words secluded by Blass. Why assume that the scribe of the archetype, at $\mathrm{A}$, would look to a similar sentence in $\mathrm{M}$ to correct the version he had in front of him - or indeed even remember that there was such a similar sentence? 
the company of other Academics in Assos, to ascribe to Plato what he later ascribes to an anonymous plurality? What would be the facts behind such a change? Jaeger does not refer to this issue of "Plato" as against the many "introducers of the Ideas", and his proposed dating leaves this problem exactly where it was. I have no solution to offer. 